\title{
Extraction Behavior of Europium with Thenoyltrifluoroacetone (TTA)
}

\author{
Nagao Ikeda, Kan Kimura, Hirokazu Asa a and Nobuko Oshima \\ Department of Chemistry, Tokyo Kyoiku University \\ Otsuka, Tokyo
}

Received November 24, 1969

\begin{abstract}
The distribution ratios of europium (II) were determined between chloroform containing thenoyltrifluoroacetone (TTA) and $0.1 M$ aqueous perchlorate solution at $25^{\circ} \mathrm{C}$, the TTA concentration in the organic phase and the hydrogen ion concentration in the aqueous phase being varied $10^{-4} \sim 10^{-1} \mathrm{M}$ and $10^{-3} \sim 10^{-7} \mathrm{M}$, respectively. The distribution behavior was explained as the extraction of the tris chelate complex into the organic phase and as the formation of the chelate complexes, $\mathrm{EuA}^{2+}, \mathrm{EuA}_{2}{ }^{+}$and $\mathrm{EuA}_{3}(\mathrm{~A}=$ anion of TTA $)$ in the aqueous phase. The following equilibrium constants were obtained graphically for the respective equilibrium reactions.

$$
\begin{array}{ll}
\mathrm{Eu}^{3+}+3 \mathrm{HA} \text { (org) } \rightleftharpoons \mathrm{EuA}_{3} \text { (org) }+3 \mathrm{H}^{+} & K_{0}=2.95 \times 10^{-9} \\
\mathrm{Eu}^{3+}+\mathrm{A}^{-} \rightleftharpoons \mathrm{EuA}^{2+} & \beta_{1}=4.5 \times 10^{4} \\
\mathrm{Eu}^{3+}+2 \mathrm{~A}^{-} \rightleftharpoons \mathrm{EuA}_{2}{ }^{+} & \beta_{2}=4.7 \times 10^{9} \\
\mathrm{Eu}^{3+}+3 \mathrm{~A}^{-} \rightleftharpoons \mathrm{EuA}_{3} & \beta_{3}=1.1 \times 10^{12}
\end{array}
$$

Distribution of $\mathrm{Eu}$ (II) was also studied. The distribution ratios for $\mathrm{Eu}$ (II) were smaller than those for $\mathrm{Eu}(\mathbb{I I})$. It was suggested that the separation of $\mathrm{Eu}$ (II) from Eu (II) may be possible at pH4.2 4.8.
\end{abstract}

\section{Introduction}

Then oyltrifluoroacetone (TTA) in various organic solvents has been widely used for the extraction of rare earth elements in aqueous solutions ${ }^{1) \sim 7)}$. Especially, the extraction behavior of europium (III) has attracted much attention in connection with the phenomena of the synergism and adduct formation. ${ }^{4), 5), 7)}$ In this paper, the extraction behavior of europium with TTA in chloroform in the $\mathrm{pH}$ range of 3.0 7.0 is elucidated in terms of the extraction equilibrium and the chelate complex formation with TTA anion in the aqueous phase.

Furthermore, separation of europium (II) from europium (III) by TTA extraction is investigated.

\section{Experimental}

\section{$2 \cdot 1$ Reagents}

${ }^{152,154} \mathrm{Eu}$ or ${ }^{155} \mathrm{Eu}$ was used in $0.1 \mathrm{M}$ perchloric acid solution as the tracer. Inactive europium solution in $0.1 \mathrm{M}$ perchloric acid was prepared from europium oxide of $99.9 \%$ purity made by Yamada Chemical Co., Ltd. The solution was labelled with a few drops of the above mentioned radioactive europium. The europium concentration of this solution was $6.6 \times 10^{-6} \mathrm{M}$. Thenoyltrifluoroacetone was supplied from Dojindo Co., Ltd. All of the other reagents used were of the reagent grade and used without any further purification.

\subsection{Procedures}

All equilibrations were carried out at $25 \pm$ $1^{\circ} \mathrm{C}$. In a $50 \mathrm{~m} l$ separatory funnel, $9.9 \mathrm{~m} l$ of a $0.1 \mathrm{M}$ sodium perchlorate-perchloric acid solution of various $\mathrm{pH}$ from a burette and 10 $\mathrm{m} l$ of a $10^{-1} \sim 10^{-4} \mathrm{M}$ chloroform solution of TTA were taken, and then $0.1 \mathrm{~m} l$ of the labelled europium solution $(0.1 \mu \mathrm{g} \mathrm{Eu})$ was added. The solutions in the separatory funnel were shaken vigorously by a mechanical shaker for more than $1 \mathrm{hr}$ and then centrifuged at $3000 \mathrm{rpm}$ for $2 \mathrm{~min}$. Five $\mathrm{m} l$ portion of each was then pipetted from each phase and transferred into a small polyethylene counting tube. The $\gamma$-activity of each solution was measured by a well-type $\mathrm{NaI}(\mathrm{Tl})$ scintillation counter. The hydrogen ion concentration in the aqueous phase was measured by transferring its small portion onto a small glass electrode of a pH-meter. 
In some experiments, back-extraction of europium from the organic phase was carried out with the equal volume of an aqueous solution. The activity of each phase and $\mathrm{pH}$ of the aqueous phase were measured in the same way.

The extraction of europium(II) was carried out after reducing europium(III) with zinc amalgam. The procedures were similar to those for europium(III) with some exceptions as follows: The amount of europium carrier added was $300 \mu \mathrm{g}$. The amalgam reduction of europium(III) was carried out in the nitrogen atmosphere, and the chloroform solution of TTA was deaerated by passing nitrogen in a 3-cocked reduction separatory funnel. The equilibration was also carried out under constant passing of nitrogen. The volume of each phase was usually $4.0 \mathrm{~m} l$, and $2.0 \mathrm{~m} l$ aliquot of each was taken for $\gamma$-counting.

\section{Results and Discussion}

3.1 Treatment of the distribution data

The distribution equilibrium of europium (III) between an aqueous phase and an immiscible organic phase with an organophilic chelating acid, HA (HA=HTTA in the present case), may be described as follows:

$$
\mathrm{Eu}^{3+}+3 \mathrm{HA}_{\text {(org) }} \rightleftharpoons \mathrm{EuA}_{3(\text { org })}+3 \mathrm{H}^{+}
$$

The equilibrium constant for this reaction is;

$$
K_{0}=\left[\mathrm{EuA}_{3}\right]_{\text {org }}\left[\mathrm{H}^{+}\right]^{3} /\left[\mathrm{Eu}^{3+}\right][\mathrm{HA}]_{\text {org }}^{3}
$$

where the subscript "org" stands for the species or concentrations in the organic phase, whereas terms without subscript denote those in the aqueous phase. The distribution ratio, $D$, is defined as;

$$
D=\left[\mathbf{E u}(\mathbb{I})_{\text {total }}\right]_{\text {org }} /\left[\mathbf{E u}(\mathbb{I})_{\text {total }}\right]
$$

where $\left[\mathrm{Eu}(\mathbb{I I})_{\text {total }}\right]$ stands for the total concentration of trivalent europium, regardless of its chemical state. By assuming that (i) europium exists in the aqueous phase as $\mathrm{EuA}_{n}{ }^{(3-n)+}(n=$ $0,1,2, \cdots, N)$ and that (ii) europium exists in the organic phase only in the form of the neutral tris chelate complex, $\mathrm{EuA}_{3}$, the equation ( 3 ) is written as;

$$
\begin{aligned}
D= & {\left[\mathrm{EuA}_{3}\right]_{\text {org }} /\left(\left[\mathrm{Eu}^{3+}\right]+\left[\mathrm{EuA}^{2+}\right]\right.} \\
& \left.+\left[\mathrm{EuAA}_{2}{ }^{+}\right]+\cdots+\left[\mathrm{EuA}_{N}^{(3-N)^{+}}\right]\right)(4)
\end{aligned}
$$

where $N$ is the maximum coordination number of $\mathrm{Eu}$ (III) for ligand A. For the complex formation reaction of

$$
\mathrm{Eu}^{3+}+n \mathbf{A}^{-} \rightleftharpoons \mathrm{EuA}_{n}{ }^{(3-n)+}
$$

the stability constant, $\beta_{n}$, is defined as follows:

$$
\beta_{n}=\left[\operatorname{EuA}_{n}{ }^{(3-n)^{+}}\right] /\left[\mathrm{Eu}^{3+}\right]\left[\mathbf{A}^{-}\right]^{n}
$$

By introducing $\beta_{n}$ in Eq. ( 4 ),

$$
\begin{aligned}
D= & {\left[\mathrm{EuA}_{3}\right]_{\text {org }} /\left[\mathrm{Eu}^{3+}\right]\left\{1+\beta_{1}\left[\mathbf{A}^{-}\right]\right.} \\
& \left.+\beta_{2}\left[\mathbf{A}^{-}\right]^{2}+\cdots+\beta_{N}\left[\mathbf{A}^{-}\right]^{N}\right\}
\end{aligned}
$$

From Eq. (2),

$$
\left[\mathrm{EuA}_{3}\right]_{\mathrm{org}}=K_{0}\left[\mathrm{Eu}^{3+}\right][\mathrm{HA}]_{\mathrm{org}}^{3} /\left[\mathrm{H}^{+}\right]^{3}
$$

therefore,

$$
\begin{gathered}
D=K_{0}[\mathbf{H A}]_{\text {org }}^{3} /\left[\mathbf{H}^{+}\right]^{3}\left\{\mathbf{1}+\beta_{1}\left[\mathbf{A}^{-}\right]\right. \\
\left.+\beta_{2}\left[\mathbf{A}^{-}\right]^{2}+\cdots+\beta_{N}\left[\mathbf{A}^{-}\right]^{N}\right\} \\
K_{0} / D\left[\mathbf{H}^{+}\right]^{3}[\mathbf{H A}]_{\text {org }}^{-3}=\mathbf{1}+\beta_{1}\left[\mathbf{A}^{-}\right] \\
+\beta_{2}\left[\mathbf{A}^{-}\right]^{2}+\cdots+\beta_{N}\left[\mathbf{A}^{-}\right]^{N}
\end{gathered}
$$

The distribution coefficient of the chelating acid between the two phases, $K_{D}$, is expressed as follows:

$$
K_{D}=[\mathrm{HA}]_{\text {org }} /[\mathrm{HA}]
$$

The dissociation constant of the chelating acid for the reaction

$$
\mathrm{HA} \rightleftharpoons \mathrm{H}^{+}+\mathrm{A}^{-}
$$

in the aqueous phase, $K_{a}$, is;

$$
K_{a}=\left[\mathbf{H}^{+}\right]\left[\mathbf{A}^{-}\right] /[\mathbf{H A}]
$$

The concentrations $[\mathrm{HA}]_{\text {org }}$ and $\left[\mathrm{A}^{-}\right]$can be calculated from the initial chelating acid concentration in the organic phase, $[\text { HA }]_{\text {org, inttial, }}$ and the observed values of $D$ and $\left[\mathrm{H}^{+}\right]$according to Eqs. (13) and (14), respectively.

$$
\begin{aligned}
& {[\mathbf{H A}]_{\text {org }}=[\mathbf{H A}]_{\text {org, } \text {, nitial }}-[\mathrm{HA}]-\left[\mathrm{A}^{-}\right]} \\
& \left.=[\mathrm{HA}]_{\text {org, inttial }}-K_{D^{-1}}{ }^{-1} \mathrm{HA}\right]_{\text {org }} \\
& -K_{D}{ }^{-1} K_{a}[\mathbf{H A}] \operatorname{org}\left[\mathrm{H}^{+}\right]^{-1} \\
& =[\mathrm{HA}]_{\mathrm{org}, \ln \mathrm{ltal}} /\left(1+K_{D^{-1}}\right. \\
& \left.+K_{D}{ }^{-1} K_{a}\left[\mathrm{H}^{+}\right]^{-1}\right) \\
& {\left[\mathbf{A}^{-}\right]=[\mathbf{H A}]_{\text {org, initial }}-[\mathbf{H A}]-[\mathbf{H A}]_{\text {org }}} \\
& =[\mathbf{H A}]_{\text {org, initial }}-K_{\mathbf{a}^{-1}}\left[\mathbf{H}^{+}\right]\left[\mathrm{A}^{-}\right] \\
& -K_{D} K_{a}^{-1}\left[\mathbf{H}^{+}\right]\left[\mathrm{A}^{-}\right] \\
& =[\mathrm{HA}]_{\text {org, initial }} /\left(1+K_{a}^{-1}\left[\mathrm{H}^{+}\right]\right. \\
& \left.+K_{b} K_{a}^{-1}\left[\mathbf{H}^{+}\right]\right)
\end{aligned}
$$

Further, the value of $K_{0}$ in Eq. (10) is obtained 
from the equilibrium data in the low $\mathrm{pH}$ region, where the concentrations of the chelate complexes $\mathrm{EuA}^{2+}, \mathrm{EuA}_{2}{ }^{+}, \ldots$ in the aqueous phase are sufficiently low, and $\beta_{1}\left[\mathbf{A}^{-}\right], \beta_{2}\left[\mathbf{A}^{-}\right]^{2}$, ... can be neglected. Then,

$$
K_{0}=D\left[\mathbf{H}^{+}\right]^{3}[\mathbf{H A}]_{\text {org }}^{-3}
$$

In Eq. (10), when the terms of $\beta_{i}\left[\mathbf{A}^{-}\right]^{i}$ with the $i$-values higher than 3 can be neglected, the equation becomes;

$$
B=\beta_{1}+\beta_{2}\left[\mathbf{A}^{-}\right]
$$

where

$$
B=\frac{1}{\left[\mathbf{A}^{-}\right]}\left(\frac{K_{0}}{D\left[\mathbf{H}^{+}\right]^{3}[\mathbf{H A}]_{\text {org }}^{-3}}-1\right)
$$

This condition is satisfied when only chelate complex formation reactions take place, and in the $\mathrm{pH}$ region where the $\log D$ vs. $\mathrm{pH}$ plot gives the slope of $3 \sim 1$. The values of $\beta_{1}$ and $\beta_{2}$ are readily obtained on the graph of $B$ vs. $\left[\mathrm{A}^{-}\right]$by measuring the intercept on the ordinate and the slope, respectively.

In the $\mathrm{pH}$ region where the slope of the $\log D$ vs. pH plot changes smoothly to less than 1, Eq. (10) may be written as:

$$
B=\beta_{1}+\beta_{2}\left[\mathbf{A}^{-}\right]+\beta_{3}\left[\mathbf{A}^{-}\right]^{2}
$$

The value of $\beta_{1}$ may be obtained as mentioned above in the low $\left[\mathrm{A}^{-}\right]$region. Then the following equation analogous to Eq. (16) may be derived;

$$
B^{\prime}=\beta_{2}+\beta_{3}\left[\mathbf{A}^{-}\right]
$$

where

$$
B^{\prime}=\left(B-\beta_{1}\right) /\left[\mathbf{A}^{-}\right]
$$

Thus, the intercept on the ordinate and the slope of the graph of $B^{\prime}$ vs. $\left[\mathrm{A}^{-}\right]$give $\beta_{2}$ and $\beta_{3}$, respectively.

3.2 Extraction data and analyses of them

The preliminary experiments showed that the values of $D$ obtained both by the extraction and the back-extraction agreed well with each other within the experimental error, revealing the attainment of the distribution equilibrium under the present experimental conditions.

The results of the measurement of the distribution ratio using $0.1 \mathrm{M}$ chloroform solution of TTA at the various $\mathrm{pH}$ values are shown in Fig. 1. The dependence of the distribution

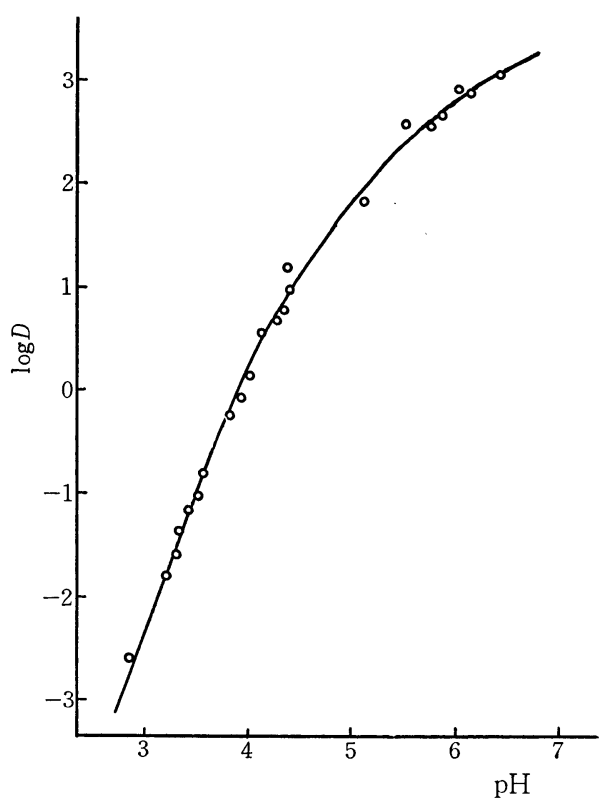

Fig. 1 Distribution ratio at the various $\mathrm{pH}$ at $25^{\circ} \mathrm{C}$.

Aqueous phase: $\mathrm{Eu}(\mathbb{I I})$ in $0.1 \mathrm{M}$ $(\mathrm{Na}, \mathrm{H}) \mathrm{ClO}_{4}$, organic phase: 0.1M TTA in $\mathrm{CHCl}_{3}$

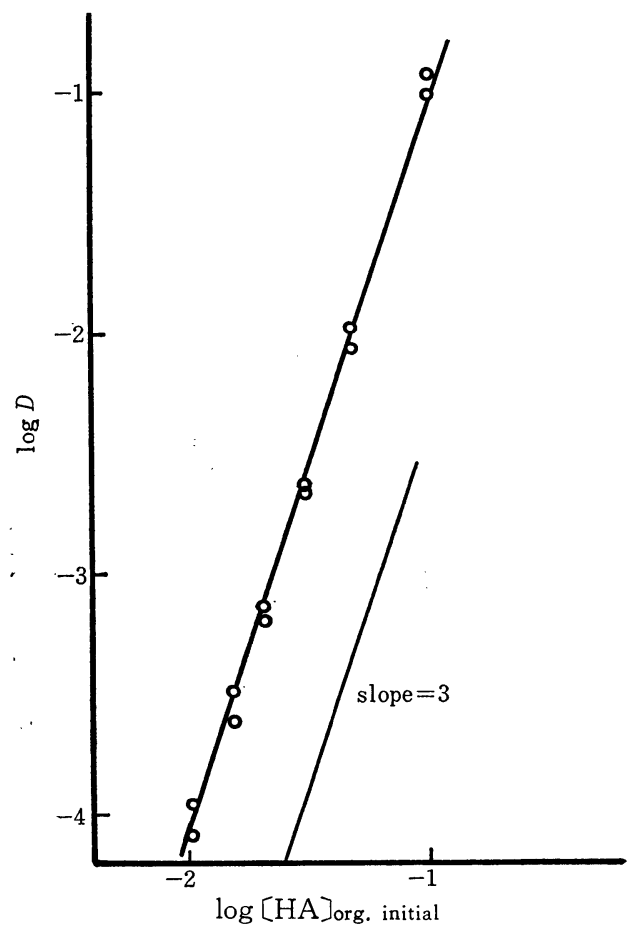

Fig. 2a The relation between distribution ratio and the initial concentration of TTA in $\mathrm{CHCl}_{3}$ at $\mathrm{pH} 3.5$. 


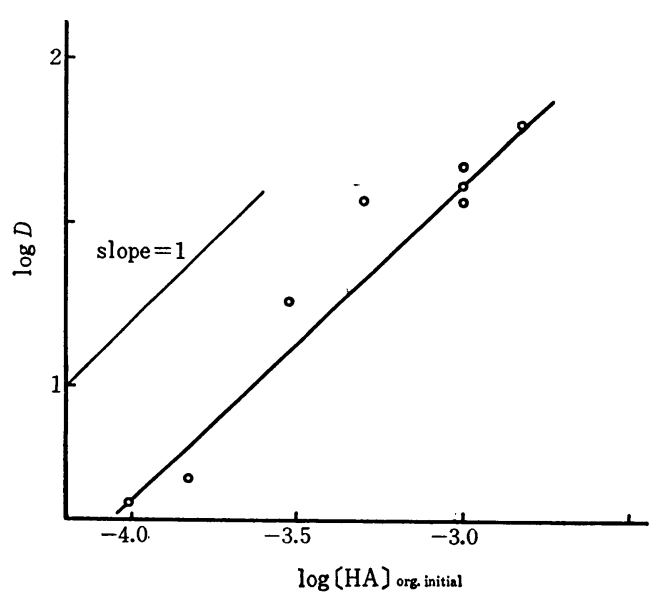

Fig. $2 b$ The relation between distribution ratio and the initial concentration of TTA in $\mathrm{CHCl}_{3}$ at $\mathrm{pH}$ 6.8.

ratio on the concentration of TTA at $\mathrm{pH} 3.5$ and $\mathrm{pH} 6.8$ is shown in Figs. $2 \mathrm{a}$ and $2 \mathrm{~b}$ respectively. It is revealed that the $\mathrm{pH}$ ranges which allow Eqs. (16) and (19) to hold good are 4.0 $\sim 6.0$, and up to $\sim 7.0$, respectively.

These experimental data are then subjected to the analyses according to Eqs. (16) and (19). The values of $K_{a}$ and $K_{D}$ are already measured to be $6 \times 10^{-7}$ and 69.2 at $25^{\circ} \mathrm{C}$, respectively8), 9). By using these data, the concentrations $[\mathrm{HA}]_{\text {org }}$ and $\left[\mathrm{A}^{-}\right]$are readily calculated according to Eqs.(13) and (14), respectively, and $K_{0}$ according to Eq. (15). The value of $B$ is then calculated and plotted vs. [ $\mathrm{A}^{-}$]. The results are shown in Fig. 3a. The linear relation between $B$ and $\left[\mathrm{A}^{-}\right]$indicates that Eq. (16) holds good in this extraction system. The values of $\beta_{1}$ and $\beta_{2}$ thus obtained are shown in Table 1. The value of $B^{\prime}$ is in turn calculated by using the numerical value of $\beta_{1}$. Fig. $3 b$ shows the relation between $B^{\prime}$

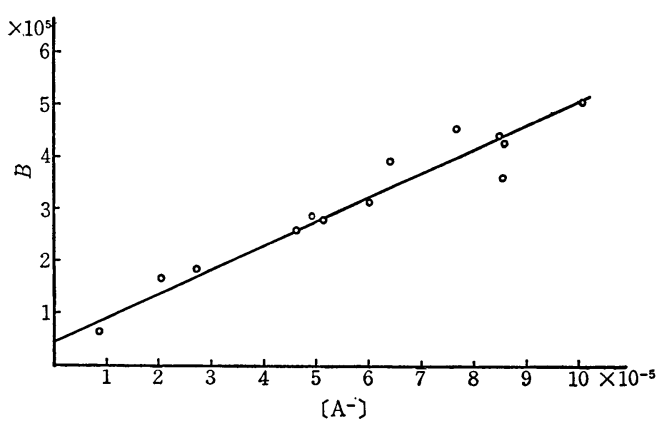

Fig. 3a Relation between $B$ and $\left[\mathrm{A}^{-}\right]$.

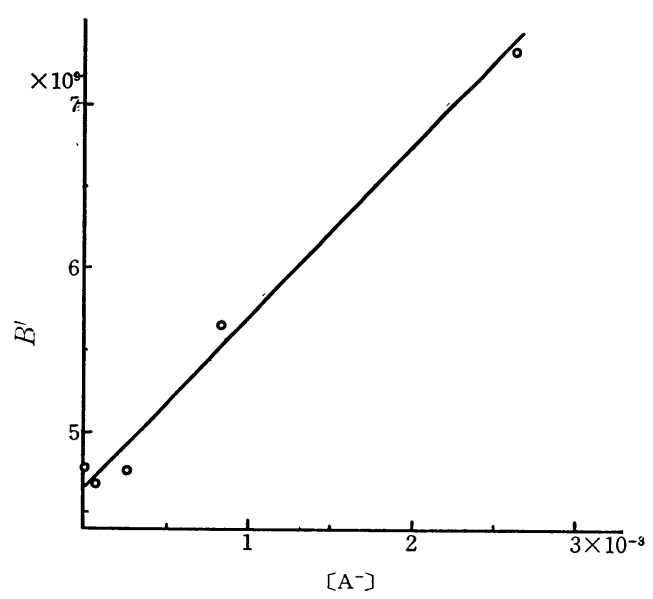

Fig. $3 \mathrm{~b}$ Relation between $B^{\prime}$ and $\left[\mathrm{A}^{-}\right]$.

and $\left[\mathrm{A}^{-}\right]$, revealing that Eq.(19) is also valid. The values of $\beta_{2}$ and $\beta_{3}$ obtained on this graph are listed in Table 1.

Table 1 The value of stability constants

\begin{tabular}{|c|c|c|}
\hline Species & Reaction & Stability constant \\
\hline $\mathrm{EuA}^{2+}$ & $\mathrm{Eu}^{3+}+\mathrm{A}^{-} \rightleftarrows \mathrm{EuA}^{2+}$ & $\beta_{1}=4.5 \times 10^{4}$ \\
\hline $\mathrm{EuA}_{2}^{+}$ & $\mathrm{Eu}^{3+}+2 \mathrm{~A}^{-} \rightleftarrows \mathrm{EuA}_{2}^{+}$ & $\beta_{2}=\left\{\begin{array}{c}4.7 \times 10^{9} \text { from } \\
\text { Fig. } 3 \mathrm{a} \\
4.7 \times 10^{9} \text { from } \\
\text { Fig. } 3 \mathrm{~b}\end{array}\right.$ \\
\hline $\mathrm{EuA}_{3}$ & $\mathrm{Eu}^{3+}+3 \mathrm{~A}^{-} \rightleftarrows \mathrm{EuA}_{3}$ & $\beta_{3}=1.1 \times 10^{12}$ \\
\hline
\end{tabular}

The stepwise chelate formation constants $K_{1} K_{2}$ and $K_{3}$ which correspond to the following reactions are calculated as shown below right:

$$
\begin{aligned}
& \mathrm{Eu}^{3+}+\mathrm{A}^{-} \rightleftarrows \mathrm{EuA}^{2+}: K_{1}=\beta_{1}=4.5 \times 10^{4} \\
& \mathrm{EuA}^{2+}+\mathrm{A}^{-} \rightleftarrows \mathrm{EuA}_{2}{ }^{+}: K_{2}=1.0 \times 10^{5} \\
& \mathrm{EuA}_{2}{ }^{+}+\mathrm{A}^{-} \rightleftarrows \mathrm{EuA}_{3}: K_{3}=2.3 \times 10^{2}
\end{aligned}
$$

The assumption (i) described in the foregoing section seems to be valid in the present extraction system, since the hydrolysis of europium in the aqueous phase may be neglected because of its low hydrolysis constant* and of the presence of the large excess of the chelating acid, and thence the mixed ligand complex formation with both $\mathrm{OH}^{-}$and $\mathrm{A}^{-}$is improbable. The formation of polynuclear complexes seems to be also improbable because of the very low total concentration of europium in the system.

The assumption (ii) seems also to be valid,

\footnotetext{
* It is reported $K=\left[\mathrm{EuOH}^{2+}\right] /\left[\mathrm{Eu}^{3+}\right]\left[\mathrm{OH}^{-}\right]=$ $10^{-8.49}$ by Frolova, et al. ${ }^{10)}$
} 
Table 2 Equilibrium constant for rare earth elements and TTA system at $25^{\circ} \mathrm{C}$

\begin{tabular}{c|c|c|c|c}
\hline Element & $\log K_{0}$ & Aqueous phase & Organic solvent & References \\
\hline \multirow{2}{*}{$\operatorname{Pr}$} & -8.47 & $0.1 \mathrm{M}\left(\mathrm{NH}_{4}, \mathrm{H}\right) \mathrm{Cl}$ & benzene & $11)$ \\
\hline \multirow{3}{*}{$\mathrm{Eu}$} & -8.53 & $0.1 \mathrm{M}(\mathrm{Na}, \mathrm{H}) \mathrm{ClO}_{4}$ & $\mathrm{CHCl}_{3}$ & this work \\
& $-8.55^{*}$ & $\prime \prime$ & $\mathrm{CHCl}_{3}$ & $4,5)$ \\
& $-8.13^{*}$ & $\prime \prime$ & $\mathrm{CCl}_{4}$ & $4,5)$ \\
\hline \multirow{3}{*}{$\mathrm{Sc}$} & -1.30 & $\prime \prime$ & $\mathrm{CHCl}_{3}$ & $9)$ \\
& -0.77 & - & benzene & $12)$ \\
\hline
\end{tabular}

* The values are calculated from the value of $D\left[\mathrm{H}^{+}\right]^{3}$ in the literature by multiplying the value of $[\mathrm{HA}]_{-\mathrm{org}}^{-3}$.

since: the third power dependence of $D$ on the TTA concentration in lower $\mathrm{pH}$ region is obtained as shown in Fig. 2a and since no remarkable deviation on the plot is observed in Figs. $3 a$ and $3 b$.

There are still very few data reported in the literature for the formation of TTA complexes in the aqueous phase ${ }^{14)}$. Sekine, Koizumi and Sakairi ${ }^{9}$ ) studied the distirbution of scandium (III) in the system of $0.1 \mathrm{M}$ sodium perchlorate+ perchloric acid solution and TTA in chloroform. They reported the value of $\log \beta_{1}$ for the reaction system of $\mathrm{Sc}^{3+}+\mathrm{TTA}^{-}$ $\rightleftarrows \mathrm{Sc}(\mathrm{TTA})^{2+}$ as 7.1 at $25^{\circ} \mathrm{C}$. As for the TTA complexes of europium(III), no stability constant has been hitherto reported.

The value of $\log K_{0}$ obtained is given in Table 2 together with the values for the systems of several rare earth elements and TTA reported in the literature. It is in very good accordance with that reported by Sekine, et al. 4),5)

\section{Extraction of bivalent europium}

The values of $\log D$ obtained are plotted against $\mathrm{pH}$ in Fig. 4 together with the corresponding values for europium(III). The values obtained in the system of $0.1 \mathrm{M}$ acetate buffer solution and $0.1 \mathrm{M}$ TTA in carbon tetrachloride are also given. The slope of the curve for europium(II) is found to be about $1 . \quad$ Nachman and Lundin ${ }^{13)}$ reported a very fast oxidation of europium (II) to europium(III) in alkyl phosphoric acid extraction of europium of low concentration. It would still remain, therefore, some possibilities of oxidation of

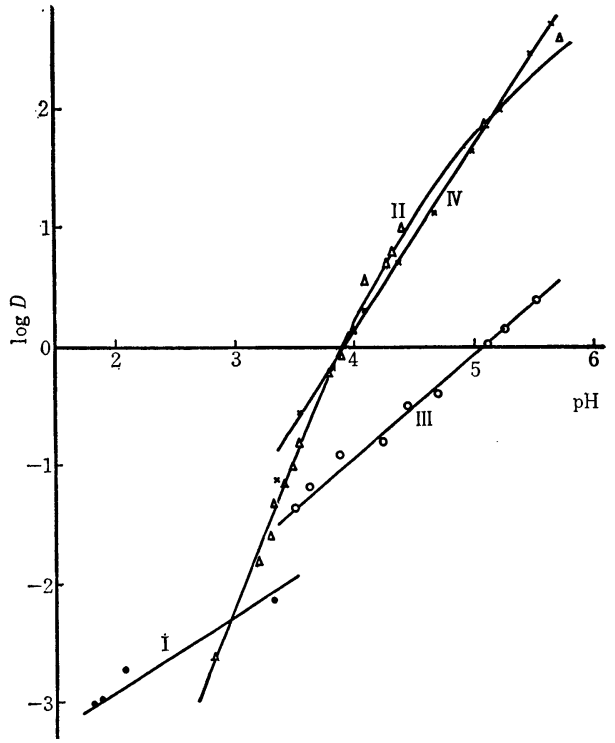

Fig. 4 Distribution ratio for $\mathrm{Eu}(\mathrm{II})$ and $\mathrm{Eu}(\mathrm{II})$ at $25^{\circ} \mathrm{C}$.

I: $300 \mu \mathrm{g} \mathrm{Eu}$ (II) in $0.1 \mathrm{M}$ perchlorate $-0.1 \mathrm{M}$ TTA in $\mathrm{CHCl}_{3}$ system

II $0.1 \mu \mathrm{g} \mathrm{Eu}(\mathbb{I I})$ in $\quad$ "

$\mathbb{I I}: 300 \mu \mathrm{g} \mathrm{Eu}(\mathbb{I})$ in $0.1 \mathrm{M}$ acetate $0.1 \mathrm{M} \mathrm{TTA}$ in $\mathrm{CCl}_{4}$ system

$\mathbb{N}: 0.1 \mu \mathrm{g} \mathrm{Eu}(\mathbb{I})$ in

europium (II) in the present experiment, although the whole procedures were done in the nitrogen atmosphere. At any rate, it seems that the values of $D$ in Fig. 4 give the upper limit of the distribution ratio of europium (II).

From Fig. 4, it is likely to be said that separation of europium(II) from europium(III) may be achieved in the present system at $\mathrm{pH}$ 4.2 4.8. 
The authors wish to express their heartfelt thanks to Dr. Fujio Ichikawa at Japan Atomic Energy Research Institute and Mr. Hitoshi Shoji at Tokyo Kyoiku University for their invaluable discussions. A part of the expenses of this work was defrayed by a grant from the Ministry of Education, to which the authors' thanks are due.

\section{References}

1) R.A. Bolomey, L. Wish: J. Am. Chem. Soc., 72, 4483 (1950)

2) L.B. Magnusson, M.L. Anderson: J.Am. Chem. Soc., 76, 6207 (1954)

3) E.K. Hyde: "Proc. Intern. Conf. Peaceful Uses of Atomic Energy", Vol. 7, United Nations, N.Y. p. 281 (1956)

4) T. Sekine, D. Dyrssen: Talanta, 11, 867 (1964); J. Inorg. Nucl. Chem., 29, 1457; $1475 ; 1481 ; 1489$ (1967)

5) T. Sekine: Nippon Kagaku Zasshi, 90, 951 (1969)
6) T. Sekine: Acta Chem. Scand., 19, 1435; $1469 ; 1476 ; 1519$ (1965)

7) H. Yoshida: Bull. Chem. Soc. Japan, 39, 1810 (1966)

8) J.C. Reid, M. Calvin: J. Am. Chem. Soc., 72, 2948 (1950)

9) T. Sekine, A. Koizumi, M. Sakairi: Bull. Chem. Soc. Japan, 39, 2681 (1966)

10) U.K. Frolova, V.N. Kumok, V.V. Serebrennikov: Izv. Vysshikh Uchebn. Zavedenii, Khim. i Khim. Tekhnol., 9, 176 (1966)

11) T.K. Keenan, J.F. Suttle: J. Am. Chem. Soc., 76, 2184 (1954)

12) J. Stary: "The Solvent Extraction of Metal Chelates", Pergamon Press, Ltd., Oxford, p. 42 (1964)

13) J.F. Nachman, C.E. Lundin, ed.: "Rare Earth Research", Gordon and Breach, N.Y. p. 15 (1962)

14) J. Rydberg: Acta Chem. Scand., 4, 1503 (1950)

\title{
要 旨
}

\section{TTA 抽出におけるユーロピウムの挙動}

\author{
池田長生, 木村 幹, 浅井弘一, 大島延子
}

東京教育大学理学部化学教室

\footnotetext{
3 価のニーロピウムの溶媒抽出挙動をテノイルトリフルオロアセトン（TTA；HA）のクロロホ ルム溶液一 $0.1 \mathrm{M}$ 過塩素酸塩系でしらべた。有機相中の TTA 濃度を $10^{-4} \sim 10^{-1} \mathrm{M}$ に変え, また水 相中の水素イオン濃度を $10^{-3} \sim 10^{-7} \mathrm{M}$ に変えたときの分配係数の変化は, $\mathrm{EuA}_{3}$ の有機相への抽出 と水相中での $\mathrm{EuA}^{2+}, \mathrm{EuA}_{2}^{+} お よ ひ ゙ ~ \mathrm{EuA}_{3}$ の生成として説明される。つぎの諸反応の平衡定数は 以下のよらである。

$\mathrm{Eu}^{3+}+3 \mathrm{HA}($ 有機相 $) \rightleftharpoons \mathrm{EuA}_{3}$ (有機相) $+3 \mathrm{H}^{+}$

$K_{0}=2.95 \times 10^{-9}$

$\mathrm{Eu}^{3+}+\mathrm{A}^{-} \rightleftharpoons \mathrm{EuA}^{2+} \quad \beta_{1}=4.5 \times 10^{4}$

$\mathrm{Eu}^{3+}+2 \mathrm{~A}^{-} \rightleftharpoons \mathrm{EuA}_{2}^{+} \quad \beta_{2}=4.7 \times 10^{9}$

$\mathrm{Eu}^{3+}+3 \mathrm{~A}^{-} \rightleftharpoons \mathrm{EuA}_{3} \quad \beta_{3}=1.1 \times 10^{12}$

2 価のユーロピウムの TTA 抽出の分配係数は対応する 3 価のユーロピウムに比べて一般に小さ

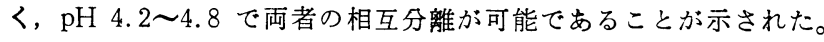

